\title{
HOMELESS IN AMERICA, HOMELESS IN CALIFORNIA
}

\author{
John M. Quigley, Steven Raphael, and Eugene Smolensky*
}

\begin{abstract}
It is generally believed that the increased incidence of homelessness in the United States has arisen from broad societal factors, such as changes in the institutionalizatio $\mathrm{n}$ of the mentally ill, increases in drug addiction and alcohol usage, and so forth. This paper presents a comprehensive test of the alternate hypothesis that variation s in homelessnes $\mathrm{s}$ arise from changed circumstances in the housing market and in the income distribution. We assemble essentially all the systematic information available on homelessness in U.S. urban areas: census counts, shelter bed counts, records of transfer payments, and administrative agency estimates. We estimate similar statistical models using four different samples of data on the incidence of homelessness, defined according to very different criteria. Our results suggest that simple economic principles governing the availability and pricing of housing and the growth in demand for the lowest-quality housing explain a large portion of the variation in homelessness among U.S. metropolitan housing markets. Furthermore, rather modest improvements in the affordability of rental housing or its availability can substantially reduce the incidence of homelessness in the United States.
\end{abstract}

\section{Introduction}

$\mathrm{T}$ HE visibility of street beggars and those sleeping in public places increased substantially about two decades ago, and the homeless became a substantive political issue at approximately the time of the inauguration of Ronald Reagan in 1981. The first of the authoritative counts of the homeless appeared shortly thereafter (Hombs \& Snyder, 1982), followed by compilations of expert opinion by government agencies (U.S. Department of Housing and Urban Development, 1984), and by estimates produced by university-based scholars (such as Rossi, 1989), nonprofit research centers (Burt \& Cohen, 1989), and by the U.S. Bureau of the Census (Taeuber, 1990). These various estimates differ substantially in methodology and definition, and their interpretation is subject to political manipulation as well as legitimate statistical controversy (Jencks, 1994; O'Flaherty, 1996; Cordray \& Pion, 1997). Nevertheless, these estimates do reveal a simple fact: the incidence of homelessness increased substantially during the $1980 \mathrm{~s}$ and has yet to decline.

Notwithstanding the debates surrounding enumeration, identifying the time trend has been considerably more successful than uncovering the underlying causes of homelessness and apportioning blame. The list of usual suspects includes the deinstitutionalization of the mentally ill, the

Received for publication August 6, 1999. Revision accepted for publication March 30, 2000.

* University of California, Berkeley.

A previous version of this paper was presented at the Annual Meetings of the American Economic Association, New York, January 1999, the Public Policy Institute of California, and elsewhere. We are grateful to John Landis, Suzanne O'Keefe, and Michael Smith-Heimer for assistance in obtaining primary data, and to Erin Mansur and Larry Rosenthal for research assistance. We are also grateful to David Levine, Harriet Newburger, Brendan O'Flaherty, and two anonymous referees for extensive comments. This work is supported by the Public Policy Institute of California and by the Berkeley Program on Housing and Urban Policy. The raw data used in this study may be downloaded at http://urbanpolic y. berkeley.edu. crack epidemic of the mid-1980s, and the relatively high cost of low-quality housing. Several prominent social scientists (in particular, Jencks (1994)) have downplayed the role of housing affordability, placing greater emphasis on deinstitutionalization and the ravaging consequences of increased drug usage. ${ }^{1}$

However, there are reasons to question these conventional explanations. The introduction of crack cocaine substantially reduced the cost of getting high, thus inducing offsetting income and price effects on housing consumption. Moreover, the onset of the crack epidemic is often dated to the mid-1980s, nearly five years after noticeable increases in homelessness (Reuter, MacCoun, \& Murphy, 1990). The decline in mental hospital populations has been largely offset by increases in the numbers of the mentally ill who are confined in other institutional settings. Hence, the number of mentally ill who are "institutionalized," broadly speaking, may not exhibit much of a trend. O'Flaherty (1996) refocuses the debate on housing costs, offering a model of urban housing markets that, when combined with the well-documented increase in income inequality during the 1980s (Reed et al., 1996), points to an increase in the incidence of homelessness.

The arguments regarding the relative importance of the various determinants of homelessness are indirect. They rely on the established fact that homelessness has increased, and they make indirect inferences from trends in potential causal factors. In this paper, we analyze directly the determinants of homelessness using essentially all the available systematic survey information about variations in the incidence of homelessness across U.S. housing markets. We analyze two national cross-sectional data sets in which the unit of observation is the city or the metropolitan area and two county-level data sets for a single large state, California. Three of these data sets correspond closely with what one might label complete counts of the "official homeless." The fourth, for California, measures homelessness among AFDC-eligible families. This latter data set is particularly useful in that it provides observations on county-level caseloads over an eight-year period; we are thus able to use standard panel techniques to address the unobserved heterogeneity which is not easily captured in simpler statistical models. $^{2}$

${ }^{1}$ A similar emphasis - and the rejection of housing market explanations - are even more apparent in the European literature on homelessness. See Fitzpatrick (1998) for a survey.

${ }^{2}$ Another homelessnes s measure for U.S. cities is a 1984 survey "based on the opinions of local officials involved with the problem of homelessness." (U.S. Department of Housing and Urban Development, 1984). This survey has been heavily criticized on methodological grounds (Rossi, 1989; Early \& Olsen, 1998) and has formed the basis for politically inspired comparisons (Tucker, 1987). Nevertheless, Honig and Filer (1993) provide a credible analysis of these data. 
We estimate comparably specified models using all four data sets and compare the results across samples. For three of these four imperfect measures of homelessness, we find that the incidence of homelessness varies inversely with housing vacancy rates and positively with the market rent for just-standard housing. In simulations intended to assess the magnitudes of these effects, we find that moderate increases in housing vacancy rates and moderate decreases in market rents are sufficient to generate substantial declines in homelessness.

\section{Housing Markets and Homelessness}

The tendency to downplay housing availability as an explanation for homelessness appears to be justified by the traits of the homeless population. Research describes a group suffering disproportionately from mental illness, drug and alcohol addiction, and extreme social isolation. Nearly one-third of the homeless suffer from mental illness and one-half abuse drugs or alcohol. Three-quarters of the homeless have been institutionalized (Burt \& Cohen, 1989; Shlay \& Rossi, 1992). In addition, point-in-time counts of the homeless (or point-prevalence estimates) suggest that the homeless constitute a small fraction of the population $(0.1 \%$ to $0.3 \%)$. Given this confluence of personal problems and the relatively low incidence of homelessness, it is tempting to dismiss the explanations of homelessness that focus on housing market conditions.

However, these arguments can also be questioned. Pointprevalence estimates fail to account for turnover among the homeless and thus understate the likelihood of experiencing a homelessness spell. Culhane et al. (1994) show that, although on any day $0.1 \%$ of the population of New York City is homeless, $1 \%$ of the population experiences homelessness over the course of a year, with larger fractions over longer periods. Moreover, turnover among the homeless suggests that point-prevalence samples are disproportionately composed of individuals suffering long spells. Phelan and Link (1999) demonstrate that this composition bias overstates the prevalence of personal problems and social isolation.

One commonly offered explanation of homelessness is the drastic reduction in inpatient populations of mental hospitals. The number of inpatients of state and county mental hospitals declined steadily during the past two decades. The rate per 100,000 dropped by almost $80 \%$ between 1971 and 1993, from 148 to 30 . The timing of deinstitutionalization, however, suggests that the conventional wisdom concerning its effect on homelessness may not be correct. Although homelessness increased substantially during the 1980 s, inpatient hospitalization rates have declined steadily since the mid 1950s. Indeed, the 67 percent reduction during the 1970s (from 148 per 100,000 in 1971 to 58 in 1980) was much larger than the $38 \%$ reduction occurring during the 1980s (from 58 in 1980 to 36 to 1990).
A further qualification to the deinstitutionalization hypothesis relates to the definition of institutionalization. Defined solely in terms of mental hospitals, institutionalization rates declined sharply during the 1980s. However, if we define institutionalization to include confinement in nursing homes, jails, and prisons, then even the direction of recent changes in the institutionalization rates is unclear. A recent report by the U.S. Department of Justice (Ditton, 1999) finds that the incidence of mental illness among prison and jail inmates is considerably higher than that for the noninstitutional population. ${ }^{3}$ In addition, prison and jail incarceration rates have increased substantially over the past three decades.

To be sure, these trends alone do not establish a transinstitutional shift of the mentally ill. A more revealing comparison is the course of within-state changes in incarceration rates as related to the pace of deinstitutionalization. This comparison is reported for prisons in figure 1. For two time periods (1972-1980 and 1981-1992), the figure presents scatter plots of state prison populations against state mental hospital populations (both expressed as deviations from state means per 100,000 state residents) along with estimates of the linear regression relationship. ${ }^{4}$ If the deinstitutionalized mentally ill are transferred into prisons, there should be a negative relationship between these two variables.

For both periods, there is a negative and highly significant relationship between the two series: in years when a state's mental hospital population is below its average level, the prison population is larger than average. The effect of mental hospitals on prisons is considerably larger for the period 1981 to 1992 (during which homelessness is commonly thought to have increased the most). This may be explained by the passage of tougher sentencing laws during the 1980s. Alternatively, if deinstitutionalization has pursued a chronologically selective path (with the least-ill patients released earlier and the most severely mentally ill individuals released (or else less likely to be committed) later), ${ }^{5}$ the more recently deinstitutionalized may be more likely to engage in behavior that results in arrest.

In a more detailed analysis of this relationship, Raphael (2000) finds that this negative correlation is quite robust. Moreover, Liska et al. (1999) find similar effects of deinstitutionalization on jail populations. Hence, for the mentally ill, incarceration is an important competing risk with homelessness. To the extent that the inmates in today's

\footnotetext{
${ }^{3}$ The DOJ study estimates that in 1996 there were 288,000 incarcerated mentally ill offenders. These offenders account for $16 \%$ of state prisoners, $7 \%$ of inmates in federal penitentiaries, and $16 \%$ of jail inmates. In contrast, approximately $2 \%$ of the general population suffers from severe mental illness (Torrey, 1997).

${ }^{4}$ For both periods, we eliminate outlier observations in the top and bottom percentiles of the deviations-from-mean $\mathrm{s}$ distribution for prison populations. Eliminating these outliers has no effect on the conclusion s we draw.

5 Jencks (1994) argues that this reconciles the disparity in timing between deinstitutionalizatio $\mathrm{n}$ and the onset of homelessness .
} 
Figure 1.-Plots of State Prison Populations (Per 100,000) against State Mental Hospital InPatient Populations (Per 100,000), Deviations from State-SPecific Means

A. $1972-1980$

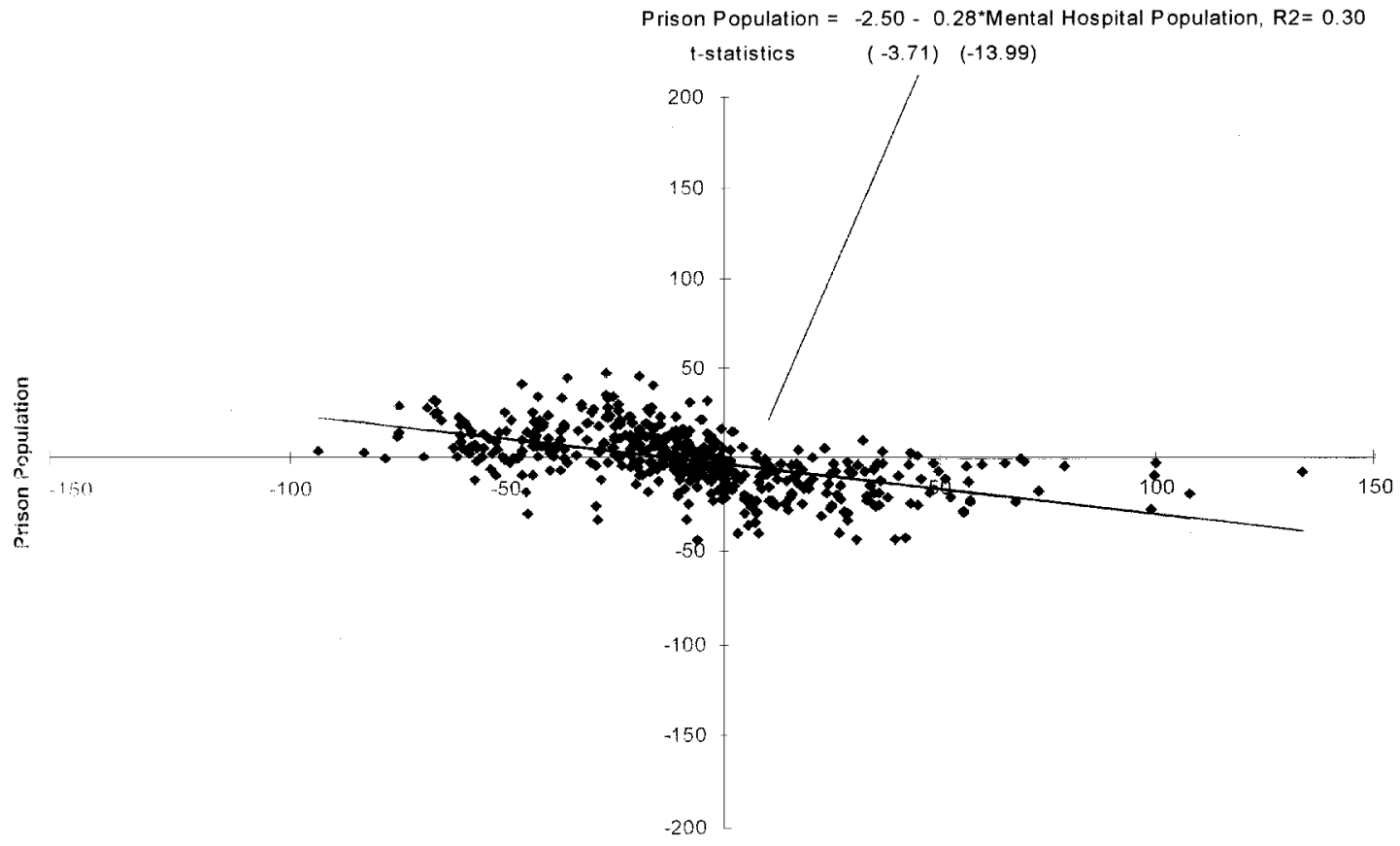

Mental Hospital Population

B. 1981-1992

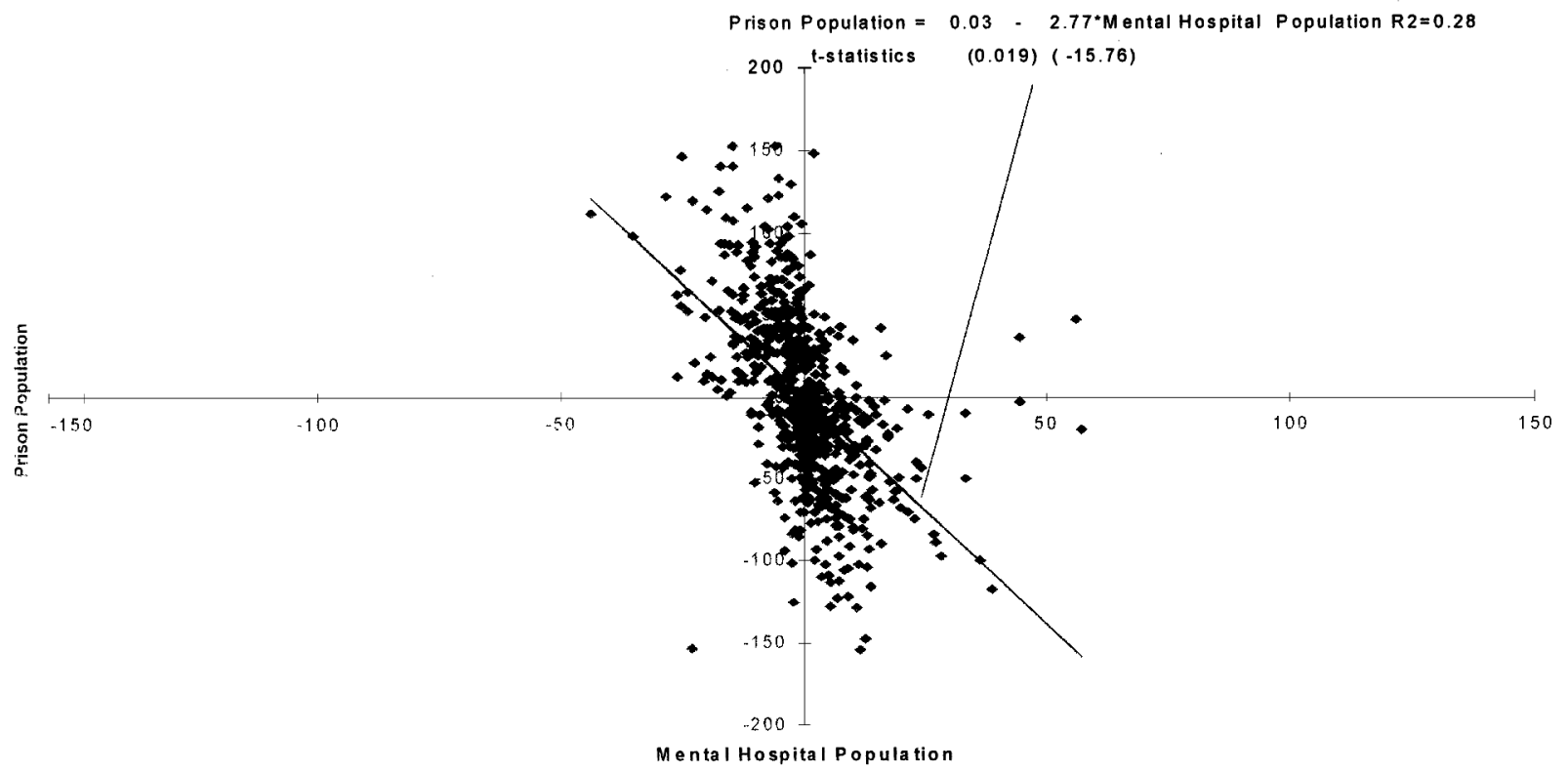

Note: All observations are measured as deviations from state-specific means over the relevant time period. 
Figure 2.-Consumers' Bid Rent for Housing and the Market-Determined Price Structure

A

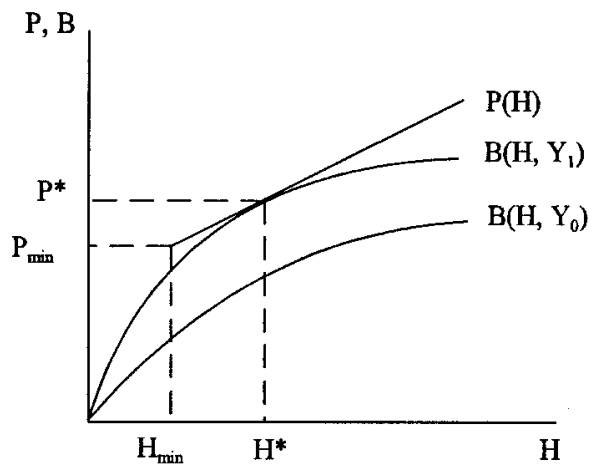

prisons and jails would have resided in state and county mental hospitals in the past, it is unclear whether the stock of prison- or hospital-eligible individuals has increased on unsupervised city streets. At a minimum, the large transinstitutional shift of mental patients casts serious doubt on the hypothesis that changes in mental health policy are the proximate causes of homelessness.

Such doubts have prompted researchers to look elsewhere. O'Flaherty's 1996 work offers a theoretical model of housing markets that, when combined with increasing income inequality, provides insight into the changing incidence of homelessness. New housing construction occurs above a certain quality threshold, and housing units filter down through the quality hierarchy and, in turn, the rent distribution, through depreciation. Below a minimum quality, rents do not justify maintenance costs, leading to abandonment by landlords or conversion of units to other uses. At the bottom of the income distribution, individual consumers must choose between the minimum quality of housing available and homelessness. Holding preferences constant, the richest, rational homeless person is just indifferent between consuming "abandonment-quality" housing at the market-determined rent on the one hand, and homelessness at zero rent on the other hand. Homelessness in this model results from decision-making under extreme income constraints and not from a preference for the "homeless lifestyle." The Hobson's choice is between consumption of very low-quality housing that absorbs a large portion of income or increased consumption of other necessities with zero housing expenditures. These theoretical arguments are supported by the empirical findings of Honig and Filer (1993). Using the 1984 HUD survey of opinions, the authors find strong relationships between measures of housing costs and informed opinion about the incidence of homelessness.

Changes in the distribution of income affect the level of homelessness through the price of abandonment-quality housing. An increase in income inequality around a stable mean (corresponding roughly to the course of incomes during the 1980s in the United States) reduces the demand

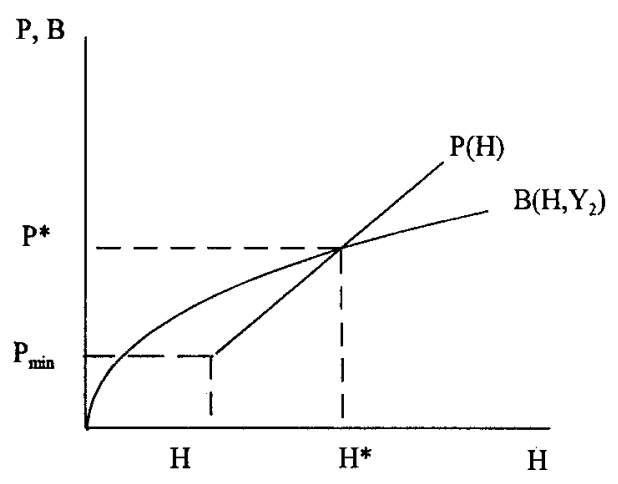

for middle-quality housing and increases the demand for low-quality housing. Households whose incomes have declined reduce their demand for housing, enter the lowerquality housing market, and bid up prices at this end of the market. Higher rents for abandonment-quality housing imply a higher cutoff-income level, below which homelessness is preferred to conventional housing.

These arguments can be illustrated with a simple model of housing choice. Assume that individuals maximize a well-behaved utility function, $\boldsymbol{U}(\boldsymbol{H}, \boldsymbol{C})$, subject to the constraint, $\boldsymbol{Y}=\boldsymbol{P}(\boldsymbol{H})+\boldsymbol{C}$, where $\boldsymbol{H}$ is the quality of housing consumed, $\boldsymbol{C}$ is a composite consumption good with a unitary price, $\boldsymbol{P}(\boldsymbol{H})$ is the price of housing of quality $\boldsymbol{H}$, and $\boldsymbol{Y}$ is income. Homelessness occurs when $\boldsymbol{H}=0$. The bid-rent function, $\boldsymbol{B}(\boldsymbol{H}, \boldsymbol{Y})$, gives the price for housing of quality, $\boldsymbol{H}$, at which an individual is indifferent between homelessness and consuming $\boldsymbol{H}$, and is defined by the condition

$$
\boldsymbol{U}(0, \boldsymbol{Y})=\boldsymbol{U}(\boldsymbol{H}, \boldsymbol{Y}-\boldsymbol{B}[\boldsymbol{H}, \boldsymbol{Y}])
$$

Define the function, $\boldsymbol{d}(\boldsymbol{H}, \boldsymbol{Y})$ as the bid rent for housing of quality, $\boldsymbol{H}$, less the market price of such housing, or $\boldsymbol{d}(\boldsymbol{H}, \boldsymbol{Y})=\boldsymbol{B}(\boldsymbol{H}, \boldsymbol{Y})-\boldsymbol{P}(\boldsymbol{H})$. A person of income $\boldsymbol{Y}$ will be homeless if and only if

$$
\max _{H} d(H, Y)<0
$$

Figure 2A graphically depicts this decision for two income levels and a linear price function. ${ }^{6}$ The function $\boldsymbol{B}(\boldsymbol{H}, \boldsymbol{Y})$ increases in housing quality at a decreasing rate. ${ }^{7}$ Note that the bid-rent function is defined only over the range in which $\boldsymbol{B}(\boldsymbol{H}, \boldsymbol{Y})$ is less than or equal to income, $\boldsymbol{Y}$. Note also that

\footnotetext{
${ }^{6}$ In general, the housing price function is not linear, and homelessnes s depend s solely on the maximum of $\boldsymbol{d}(\boldsymbol{H}, \boldsymbol{Y})$. For simplicity, however, we depict linear price functions in figures $2 \mathrm{~A}$ and $2 \mathrm{~B}$.

${ }^{7}$ Equation (1) implies $0=\boldsymbol{U}_{\boldsymbol{H}}-\boldsymbol{U}_{\boldsymbol{C}} \boldsymbol{B}_{\boldsymbol{H}}$ or $\boldsymbol{B}_{\boldsymbol{H}}=\boldsymbol{U}_{\boldsymbol{H}} / \boldsymbol{U}_{\boldsymbol{C}}$. The RHS is the absolute value of the marginal rate of substitution. With diminishing marginal utility, $\boldsymbol{B}$ increase s in $\boldsymbol{H}$ at a decreasing rate.
} 
$\boldsymbol{B}(\boldsymbol{H}, \boldsymbol{Y})$ is increasing in $\boldsymbol{Y}$; workers with higher incomes will bid more to avoid homelessness. ${ }^{8}$

The price function for housing, $\boldsymbol{P}(\boldsymbol{H})$, is determined by demand and supply in the housing market, with price increasing with housing quality. Tighter markets are represented by higher price schedules. Housing suppliers must abide by minimum standard regulations (for example, regulations requiring that all units must have an indoor toilet), so the market will not offer housing below some quality threshold. The price schedule has a discontinuity at some positive price.

In figure 2A, households of income $\boldsymbol{Y}_{1}$ are indifferent between homelessness and consumption of $\boldsymbol{H}^{*}$. These households have income levels that are just high enough to place them in conventional housing. Households of income $\boldsymbol{Y}_{0}$ will prefer homelessness to any housing available in the market because they cannot "afford" housing of any quality offered in the market. In figure 2B, households of income $\boldsymbol{Y}_{2}$ are indifferent between homelessness and consumption of $\boldsymbol{H}^{*}$ housing at prevailing prices. However, for housing quality levels below $\boldsymbol{H}^{*}$ and above $\boldsymbol{H}$ min, by buying housing in the market, these households would attain even higher utility levels than at $\boldsymbol{H}^{*}$ (as is clear from the difference between the amount that they are willing to pay to avoid homelessness and the market price).

This simple demand model yields several empirical predictions. For example, the model suggests that a greater disparity between the distributions of housing rents and income (measured, for example, by the ratio of median rents to median income) leads to a higher incidence of homelessness. When combined with a model of housing supply, this simple model predicts that, holding constant the distribution of housing costs, the incidence of homelessness will be greater if household income is more unequally distributed. ${ }^{9}$ We next outline several empirical tests that explore these possibilities.

\section{Measures of Homelessness}

We rely upon four sources of data in investigating the link between housing market conditions and homelessness. The first two data sources are national in coverage (the S-night census and Burt shelter counts), and the other two describe homelessness in California counties (the continuum-of-care reports and administrative data from the AFDC-HAP program). Here we describe the basic features of these data sets along with their comparative strengths and weaknesses.

\footnotetext{
${ }^{8}$ To see this, differentiate equation (1) with respect to $\boldsymbol{Y}$, yielding $\boldsymbol{U}_{\boldsymbol{C} \mid \boldsymbol{C}=\boldsymbol{Y}}=\boldsymbol{U}_{\boldsymbol{C} \mid \boldsymbol{C}<\boldsymbol{Y}}\left(1-\boldsymbol{B}_{Y}\right)$ or $\boldsymbol{B}_{\boldsymbol{Y}}=1-\left(\boldsymbol{U}_{\boldsymbol{C} \mid \boldsymbol{C}=\boldsymbol{Y}}\right) /\left(\boldsymbol{U}_{\boldsymbol{C} \mid \boldsymbol{C}<\boldsymbol{Y}}\right)$. With diminishing marginal utility, $\boldsymbol{U}_{\boldsymbol{C} \mid \boldsymbol{C}=\boldsymbol{Y}}<\boldsymbol{U}_{\boldsymbol{C} \mid \boldsymbol{C}<\boldsymbol{Y}}$, and $\boldsymbol{B}_{\boldsymbol{Y}}$ is always positive.

${ }^{9}$ This result depends upon a filtering model of housing supply in which high-quality housing is built and low-quality housing is produced by depreciation and maintenance policies (called "cheap construction" by O'Flaherty, 1995). See Mansur et al. (2000) for a more complete discussion.
}

\section{A. The S-Night Enumeration}

As part of the 1990 Census, the U.S. Census Bureau sought to enumerate the homeless population on a single night in urban places with populations in excess of 50,000. The "S-night" (street and shelter night) enumeration of March 20-21, 1990, consisted of three components. First, from 6 p.m. to midnight, enumerators counted all of the homeless sleeping or staying at a predesignated list of shelters (intended to be a complete listing of all known shelters). Next, between 2 a.m. and 4 a.m., enumerators attempted to count homeless people on the streets at locations designated by local officials as known congregating areas for the homeless. Finally, later that morning, enumerators attempted to count all individuals exiting abandoned buildings (Write \& Devine, 1992). The sum of these three components provides an estimate of the homeless population in 1990 for each city. We use these data aggregated to the metropolitan area (MSA) as our first measure of homelessness.

It is widely believed that the 1990 Census S-night enumeration substantially undercounted the homeless (Hudson, 1993). Although the Census Bureau estimated a 1990 homeless population of 230,000 , the concurrent consensus among researchers was a population between 550,000 and 600,000 (Burt \& Cohen, 1989). Several factors contributed to the undercount. For instance, the lists of shelters as well as street locations where the homeless congregated were incomplete. ${ }^{10}$ Also, evaluations of the enumeration efforts (sponsored by the Census Bureau) indicated that, for many of the listed street locations and shelters, enumerators either failed to visit the site or did not follow the predetermined protocol in counting the number of people at the location. ${ }^{11}$

An undercount consistent across metropolitan areas would not affect our statistical analysis. However, if the degree of undercounting varies systematically with measures of housing costs, the results reported below may be biased. Although we do not have information on the degree of undercounting for all areas, some suggestive data exist. To evaluate S-night, the Census Bureau sponsored research in five cities in which "decoys" were deployed to the listed street locations for three purposes: to observe the behavior of enumerators (for example, whether or not they showed up and followed directions), to estimate the number of homeless at visited locations, and to report whether they themselves had been counted. The proportion of counted decoys provides a rough estimate of the degree of undercounting across these five cities.

\footnotetext{
${ }^{10}$ For example, in Chicago, street locations were generated by the Chicago Police Department without consulting local service providers, advocates, or the homeless (Edin, 1992).

${ }^{11}$ For example, in Chicago, enumerator s dropped off census forms at the largest shelter whose staff made forms available to anyone who wanted to complete one (Edin, 1992). Reasons for the spotty enumeration efforts include poor training (Hopper, 1992), poorly defined geography with frequently incorrect addresses (Edin, 1992), as well as the concerns of enumerators for their personal safety.
} 
The percentages of decoys explicitly indicating that they had not been counted (from lowest to highest) was $10 \%$ in New Orleans, $10 \%$ in Phoenix, 13\% in Los Angeles, 20\% in New York, and 25\% in Chicago (Martin, 1992). Estimated rents in 1990 for a two-bedroom apartment in the surrounding PMSA ${ }^{12}$ were New Orleans \$485, Phoenix \$557, Los Angeles \$715, New York \$593, and \$604 for Chicago. Hence, with the exception of Los Angeles, the degree of undercounting was greater in high-rent PMSAs. If this pattern generalizes to all metropolitan areas, bivariate estimates of the effects of housing costs on homelessness using the S-Night data will be biased downwards.

\section{B. The Burt Survey}

Almost concurrent with S-night, the Urban Institute surveyed local officials in major cities to establish the number of beds that were available to house the homeless. Martha Burt, principal investigator, obtained lists of shelter providers from the Comprehensive Homeless Assistance Plans submitted to HUD by local officials. She supplemented these lists with shelter providers identified by nongovernmental organizations and coordinators of homeless services. All cities with populations exceeding 100,000 in 1986 were surveyed. The sample includes 147 central cities and 35 suburban jurisdictions. We analyze these counts aggregated up to the surrounding metropolitan statistical area.

A major methodological problem associated with using shelter-bed capacity to study the determinants of homelessness is that shelter-capacity measures a public-policy response to homelessness rather than homelessness itself. Although the severity of a city's homeless problem surely affects shelter capacity, other factors may have independent effects on shelter capacity, and these may bias cross-sectional inferences on the determinants of homelessness drawn from these data. For example, O'Flaherty (1996) argues that, if homeless services are normal goods, wealthier cities will allocate more funds for homeless shelters, thus introducing a spurious positive correlation between this measure of homeless and mean household income. Alternatively, wealthier areas may devote fewer resources to homeless shelters (or oppose the opening of shelters through local land-use controls) so as not to attract the users of such services. If rents are higher in wealthier areas, this activity would weaken the relationship between homelessness (as measured by shelter capacity) and local rents. ${ }^{13}$ Further, shelter usage necessarily undercounts the homeless simply

\footnotetext{
12 These are estimates of rents at the fortieth percentile of the rental distribution and are calculated for local housing markets by HUD using data from the American Housing Survey.

${ }^{13}$ Moreover, changes in housing assistance policies for low-income families may affect the size of the shelter population independently of changes in the severity of a city's homeless problem. Cragg and O'Flaherty (1999) assess whether the priority that the Dinkins administration placed on placing homeless families in subsidized housing contributed to the increase in the New York City shelter population observed in the early 1990s. The authors do find a small increase in shelter population s caused by the shift in policy. However, the effect is small and
}

because all homeless do not stay in shelters. Moreover, there is little reason to believe that street-to-shelter ratios are constant across metropolitan areas. ${ }^{14}$

Despite these criticisms, the Burt data were collected with careful attention paid to consistency across cities. Moreover, experts speculate that the cross-sectional variation in shelter availability is highly correlated with actual variation in the incidence of homelessness. ${ }^{15}$

\section{Continuum-of-Care Homeless Counts for California}

Since 1994, HUD has provided support under the Super Notice of Fund Availability (NOFA) program to assist homeless persons to achieve self-sufficiency and permanent housing. ${ }^{16}$ Eligible counties seeking funding must submit a "continuum of care" plan to HUD. These plans justify community requests for funding under a variety of federal programs such as the Supportive Housing Program and the Shelter Plus Care Program. Two major reasons for requiring these plans is to enforce consistent estimates of the numbers of homeless persons by type of housing need, and to produce comparable estimates of the availability of housing by type to meet these needs. The guidelines for completion of these plans attempt to enforce a common structure for estimates of the incidence of homelessness at a single point in time (U.S. Department of Housing and Urban Development, 1994).

Despite the emphasis on uniformity, close examination of these counts for California counties reveals considerable variation in the estimation methods used. Rosenthal (2000) notes that no fewer than twelve different methods were used in generating continuum-of-care estimates in the state. ${ }^{17}$ In addition, Rosenthal notes that, when several local estimates were available, local officials often presented some combination of them with no explanation of the weights placed on the various sources nor the reasoning. This heterogeneity undoubtedly results in a noisy and perhaps biased data set.

explains little of the increase in the city's shelter population observed between 1990 and 1993.

${ }^{14}$ An additional concern that applies to both the Burt and S-night data is that there are large disparities across the two data sets concerning the number of shelter beds (or for S-night, the number of people residing in shelters), despite the fact that the surveys were conducted in the same month and year (O'Flaherty, 1996). This is reflected in our samples. The homelessnes s rates from Burt and S-night are far from perfectly correlated $(\boldsymbol{r}=0.560)$. Although the error may lie with the Census Bureau, these disparities are indicative of the difficulties inherent in counting the homeless. They also provide justification for the cumulative approach taken here.

${ }^{15}$ For example, Burt's shelter-bed counts are strongly correlated with earlier counts of the homeless population conducted by the Urban Institute in $1987(\boldsymbol{r}=0.934)$ and by HUD's 1984 survey $(\boldsymbol{r}=0.827)$ (Burt, 1992). However, this evidence is not particularl y reassuring if these earlier counts suffer comparable methodological shortcomings.

${ }^{16}$ Nationwide appropriations for HUD's homeless assistance program totaled \$923 million in 1998; appropriation s for fiscal year 1999 were $\$ 975$ million.

${ }^{17}$ Among the alternatives are census S-night counts, unduplicate d shelter surveys, local area studies, AFDC-HAP program data, extrapolation s from national estimates, and post S-night street counts. 
Bonnewit (1998) assembled these reports for the 33 counties in California that were eligible for funding under the Super NOFA program, identified comparable published information for 19 of the 25 non-entitlement counties, and estimated homeless counts for the remaining six counties. The data provide estimates by county of the number of homeless individuals and the number of homeless family members for a point in time in 1996 or 1997 . We restrict the analysis to counties reporting some homelessness (50 of the 58). These counts imply that there are approximately 361,000 homeless in California. This is a very large number, comprising $1.1 \%$ of the state population. (In comparison, recall that most estimates of the national homeless population lie between $0.1 \%$ and $0.3 \%$.) Although we believe that the continuum-of-care data substantially overcount the homeless population, we cannot assess the potential bias from overcounting. ${ }^{18}$

\section{The California Homeless Assistance Program}

Each state may choose to operate an "Emergency Assistance Program for needy families with children (whether or not eligible for AFDC) if the assistance is necessary to avoid the destitution of the child or to provide living arrangements in a home for the child" (U.S. House of Representatives, 1991, p. 592). In California, emergency assistance is provided through the Homeless Assistance Program (HAP), established in 1988 as a component of Aid to Families with Dependent Children (AFDC). The HAP program provides payments to AFDC-eligible (or apparently eligible) families that need shelter due to homelessness. (The program is now subsumed within the postwelfare reform CAL-WORKS program.) Homelessness under AFDC-HAP exists when a family lacks a fixed and regular nighttime residence or is living either in a supervised temporary shelter or "in a public or private place not designed for, or ordinarily used as, a regular sleeping accommodation by human beings." In practice, a family with children literally has to be on the street with nowhere to go before qualifying for aid. ${ }^{19}$

AFDC-HAP provides two types of benefits to homeless families. For a fixed period (currently sixteen days), "temporary assistance" provides shelter expenses that increase with family size. The disbursement of funds under the temporary assistance program is subject to verification of shelter expenditures and housing search. "Permanent assistance" provides reimbursement for move-in costs such as security and utility deposits. ${ }^{20}$ We analyze the determinants of annual caseloads of both the temporary- and permanentassistance programs. Even during the least-restrictive years,

\footnotetext{
${ }^{18}$ Presumably, larger counts indicate a greater "need" for HUD discretionary grants.

${ }^{19}$ This interpretation comes from several conversation s with knowledgeable representative s of the California Department of Social Services, the agency that administers AFDC-HAP.

${ }^{20}$ We obtained monthly data on temporary- and permanent-assistanc e caseloads. These caseloads were summed within years to arrive at a count of the number of families receiving assistance during the year.
}

assistance was limited to once per year; thus, annual caseloads do not double-count homeless families that suffer multiple spells. Program regulations changed several times, most notably in 1996 when eligibility was limited to once per lifetime. Hence, in the statistical models estimated below, we include fixed effects for each year to control for the year-to-year variation in program regulations that is common to all counties. We also include fixed effects for each of California's 58 counties. The data cover the period from 1989 to 1996.

\section{Empirical Strategy}

We use the four data sets to test for a relationship between homelessness and measures of housing availability and labor market conditions. These four measures complement each other in many respects. An advantage of the Burt survey is the consistency of enumeration methods across cities. The disadvantages are that there is hardly a one-toone relationship between shelter beds and homeless persons, and that inter-city variation in shelter capacity may simply reflect variation in local policy responses rather than the extent of homelessness. An advantage of the S-night enumeration is that it attempts to count fully the homeless population rather than the capacity of service providers. A major disadvantage, however, is that the S-night enumeration may have undercounted the homeless in a nonrandom manner. Both data sets are based upon reasonably large samples, 269 MSAs in the census enumeration and 119 cities in the Burt data. In addition, with national coverage, interstate variation in the policies that govern the inpatient rates in mental hospitals can be used to test for an effect of deinstitutionalization on the incidence of homelessness.

However, unobserved interstate and intermetropolitan variation in housing assistance programs may have important effects on homelessness. If such unmeasured services are related to the variables included in our statistical models (such as vacancy rates and rents), the results estimated from these national samples may be biased. This qualification, however, is less important for the two California measures, because variation in the incidence of homelessness occurs under a similar set of state institutions. Moreover, the AFDC-HAP data set provides an eight-year panel of county observations. This permits us to control for county-specific fixed effects, thus eliminating any intercounty fixed factors that affect homelessness. By estimating comparable models for all data sets, the within-county results from AFDC-HAP provide a consistency check on the three sets of crosssectional results.

The continuum-of-care and AFDC-HAP data complement each other in that they pertain to different subgroups within the population most likely to suffer homelessness. A component of the continuum-of-care series corresponds more closely to visible homelessness, namely predominantly single men who suffer disproportionately from the effects of mental illness and substance abuse. The AFDC- 
HAP caseloads correspond to intact families with children who become homeless. A priori, one expects larger effects of housing and labor market conditions for the latter group than for the former. Hence, analyzing both data sets may yield some comparative insights. Based on Rosenthal's (2000) description, however, we think the quality of the continuum-of-care data is low.

We test for relationships between homelessness and several variables. We analyze the effects of housing vacancy rates and median rents on homelessness. If homelessness is a housing market problem, one expects a negative effect of vacancy rates and a positive effect of rents. We also explore the effects of measures of household or per capita income, the proportion of residents who are poor (with incomes less than $\$ 15,000)$, and local unemployment rates. To the extent that homelessness is determined by insufficient income or slack labor markets, homelessness should be positively correlated with the unemployment rate and negatively correlated with median incomes. Moreover, the larger the pool of poor households, the greater the population at risk of a spell of homelessness.

We present two specifications for the S-night, Burt, and continuum-of-care data, intending to reflect the mismatch between the distribution of housing prices and the distribution of incomes. First, we include a regressor measuring the ratio of median rent to median household income for the S-night and Burt samples, and the ratio of fair market rents to per capita income for the continuum-of-care sample. Higher rents relative to income should be positively correlated with the cross-sectional incidence of homelessness. We also estimate a similarly specified model using the AFDC-HAP panel.

A more precise implication of the economic model is that homelessness increases with the degree of income inequality. We evaluate this prediction by regressing homelessness on vacancy rates, median rents, the proportion of households poor (that is, the fraction with 1989 annual incomes below \$15,000), and median household income. Holding constant the proportion of households in the lower tail of the income distribution, higher median household incomes indicate greater levels of earnings inequality. The model predicts that median household income will be positively related to the incidence of homelessness. Because the proportion of low-income households is measured only at Census years, we are unable to estimate a comparable specification using the HAP panel.

To be sure, our key explanatory variables (rents and vacancy rents) are the endogenous outcomes of regional housing markets. These variables are determined simultaneously by supply-and-demand conditions in the various housing submarkets and search frictions that impede the instantaneous matching of households to housing units. One strategy that would allay concerns about causality would be to identify exogenous variables that determine rents and vacancy rates and use these as instruments in our homeless models. Such variables may include inter-city difference in construction costs, natural limits to the supply of land, or differences in zoning regulations that affect housing costs. Unfortunately, such variables are difficult to quantify for our cross sections and nearly impossible to measure within county for our panel data set. ${ }^{21}$ In any event, the small size of the homeless population may justify the assumption that rents and vacancy rates are exogenously determined. It is unlikely that the housing demands of those individuals in the bottom $0.1 \%$ to $0.3 \%$ of the income distribution exert a measurable effect on regional rent levels. In other words, our reduced-form analysis treats the homeless as pricetakers whose consumption decisions have no impact on local rents due to their small numbers. In addition, if the principal problem with OLS estimates of the relationship between homelessness and housing availability is omittedvariables bias rather than simultaneity, controlling for fixed effects in our AFDC-HAP models will partially address this concern.

We include a number of additional covariates in our models. In all models, we control for January temperature and the incidence of disability income (SSI) receipt in each market. ${ }^{22}$ For the two national data sets, we attach statelevel measures of the changes in the inpatient population of mental hospitals and in prison population per 100,000 state residents between 1980 and 1990. Because homelessness is a less attractive option in colder areas, we expect a positive relationship between January temperatures and homelessness. For the shelter-counts measure, the tendency for local authorities to increase capacity during cold spells (via temporary shelters) may simply mask the effect of temperature on homelessness. The effect of the SSI population is unclear because a larger recipient population may indicate either a larger population at risk or a greater effectiveness of local service providers in connecting the potentially homeless to

\footnotetext{
${ }^{21}$ For the two national data sets, we sought instruments for rents and vacancy rates, concentrating on several variables intended to measure exogenous constraints on the supply side of housing markets. These variables included indicators of whether an MSA's topography is amenable to housing construction (plains, hills, and so on), the proportion of land area covere d by water, and a measure of the extent of regulation in local land and housing markets. (The former measures were based upon the natural amenities index maintained by the U.S. Geological Survey; the latter measure was based on the regulation index reported in Malpezzi, Chun, and Green (1996).) We found a significant relationship between rents and the land-use regulation variable-and between rents and the water measure-but no relationship between rents and the topography measure in these data sets. When rents are regressed on both the Malpezzi index and the water-area measure, only the Malpezzi index remains significant. Using the regulation index as an instrument for rents (1996), we estimated IV models for the S-night and Burt samples similar to the specifications presented below. These results support the findings and conclusions presented below and are available upon request. We also attempted to use the regulatory index develope d by Gabriel et al. (1999) for nineteen California counties as an instrument for county-level rents in the continuum-of-care models. Here, however, there was no first-stage relationship between rents and the Gabriel index. We were unable to find an instrument that varies by county and year for the AFDC-HAP models.

${ }^{22}$ SSI recipients are reported by county. For cities, we use the rate for its corresponding county. For MSAs, we aggregate counties.
} 
Table 1.-Mean Homeless Rates and Means of the Explanatory Variables for Census S-Night (1990) Counts and Burt Counts of Shelter Beds (1989), Full Sample, and Stratified by Metropolitan Areas with Below- and Above-Median Homeless Rates

\begin{tabular}{|c|c|c|c|}
\hline \multicolumn{4}{|c|}{ Panel A. S-night Counts } \\
\hline Variable & Full Sample & $\begin{array}{l}\text { Below-Median } \\
\text { Homelessness }\end{array}$ & $\begin{array}{l}\text { Above-Median } \\
\text { Homelessness }\end{array}$ \\
\hline Homeless per 10,000 & $11.120(0.468)$ & $4.211(0.117)$ & $14.110(0.636)$ \\
\hline Rental vacancy rate (percent) & $8.414(0.190)$ & $9.143(0.259)$ & $8.098(0.269)$ \\
\hline Median gross rent & $480.588(6.280)$ & $400.299(4.980)$ & $515.325(8.550)$ \\
\hline Median HH income (1000s) & $32.758(0.332)$ & $28.966(0.321)$ & $34.398(0.454)$ \\
\hline Households $<\$ 15 \mathrm{~K}$ (percent) & $21.847(0.306)$ & $25.075(0.412)$ & $20.451(0.385)$ \\
\hline $\begin{array}{l}\text { Median gross rent/median } \\
\text { household income (percent) }\end{array}$ & $1.465(0.010)$ & $1.385(0.011)$ & $1.497(0.014)$ \\
\hline $\begin{array}{l}\Delta(90-80) \text { state mental patients } \\
\text { per } 100,000 \text { residents }\end{array}$ & $-20.598(1.050)$ & $-23.648(1.520)$ & $-19.279(1.470)$ \\
\hline$\Delta(90-80)$ state prisoners per & & & \\
\hline 100,000 residents & $162.817(6.160)$ & $146.574(4.780)$ & $169.276(9.670)$ \\
\hline January temperature $\mathrm{e}^{\mathrm{a}}$ & $32.884(0.867)$ & $25.662(0.973)$ & $36.012(1.223)$ \\
\hline SSI Recipients per 10,000 & $191.420(4.665)$ & $176.170(5.635)$ & $198.021(6.913)$ \\
\hline Unemployment rate (percent) & $6.211(0.086)$ & $6.518(0.136)$ & $6.079(0.115)$ \\
\hline Number of observations & 270 & 135 & 135 \\
\hline \multicolumn{4}{|c|}{ Panel A. Burt Shelter Counts } \\
\hline Variable & Full Sample & $\begin{array}{l}\text { Below-Median } \\
\text { Homelessness }\end{array}$ & $\begin{array}{l}\text { Above-Median } \\
\text { Homelessness }\end{array}$ \\
\hline Homeless per 10,000 & $23.543(1.324)$ & $11.202(0.351)$ & $33.295(1.567)$ \\
\hline Rental vacancy rate (percent) & $8.373(0.277)$ & $8.861(0.378)$ & $7.987(0.400)$ \\
\hline Median gross rent & $495.803(9.283)$ & $474.028(13.550)$ & $513.011(12.420)$ \\
\hline Median HH income (1000s) & $33.776(0.473)$ & $31.996(0.542)$ & $35.184(0.706)$ \\
\hline Households $<\$ 15 \mathrm{~K}$ (percent) & $21.017(0.406)$ & $22.372(0.573)$ & $19.945(0.537)$ \\
\hline $\begin{array}{l}\text { Median gross rent/median } \\
\text { household income (percent) }\end{array}$ & $1.463(0.014)$ & $1.473(0.024)$ & $1.456(0.018)$ \\
\hline $\begin{array}{l}\Delta(90-80) \text { state mental patients } \\
\text { per } 100,000 \text { residents } \\
\Delta(90-80) \text { state prisoners per }\end{array}$ & $-19.736(1.553)$ & $-14.097(1.731)$ & $-24.193(2.352)$ \\
\hline 100,000 residents & $167.671(10.09)$ & $168.109(8.130)$ & $167.352(16.730)$ \\
\hline January temperature ${ }^{\mathrm{a}}$ & $35.358(1.273)$ & $36.036(2.030)$ & $34.822(1.608)$ \\
\hline SSI Recipients per 10,000 & $192.803(6.769)$ & $199.852(9.379)$ & $187.221(9.734)$ \\
\hline Unemployment rate (percent) & $6.193(0.120)$ & $6.622(0.179)$ & $5.855(0.148)$ \\
\hline Number of observations & 116 & 58 & 58 \\
\hline
\end{tabular}

Standard errors are in parentheses.

${ }^{a}$ One half of the sum of the January average high temperature and the January average low temperature.

the available program support. Changes in the inpatient and prison populations should be negatively associated with homelessness.

Table 1 presents descriptive statistics for the homeless counts and accompanying explanatory variables for the two national samples. ${ }^{23}$ The table presents means for the full samples and for the samples stratified into metropolitan areas (or cities) with above- and below-median homelessness rates (as calculated for the separate samples). For both national data sets, the housing variables are associated with homelessness. Rental vacancy rates are lower in abovemedian areas, and rents are lower in areas with belowmedian homelessness. The rents-to-income ratios are higher

${ }^{23}$ With the exception of the January temperature, change in inpatients and prisoners, and the SSI measure, all other variables come from the 1990 Census Summary Tape Files. State mental inpatient population s come from various years of Mental Health Statistical Notes. Data on SSI program recipients come from the U.S. Social Security Administration; data for January temperatures come from the 1995 Statistical Abstract of the United States, Rand McNally, and the National Weather Service. Details concerning the construction of this variable are available upon request. Data on state prison populations are published by the Bureau of Justice Statistics. in high-homelessness areas for the S-night sample, but lower for the Burt sample.

A major difference between the two samples concerns the association between homelessness and the extent of deinstitutionalization. For the S-night measure, the decline in the inpatient population is negatively associated with homelessness. This pattern is particularly striking and contrasts with the widely held presumption about the role of deinstitutionalization during the 1980s. For the Burt measure, cities with above-median homelessness are in states with higher-than-average declines in inpatient populations. This pattern may reflect local policy responses to deinstitutionalization. Changes in prison populations are positively associated with homelessness for the S-night data and unrelated for the Burt data. These results for prison populations are counterintuitive because one expects that high incarceration rates remove potentially homeless people from city streets.

Table 2 presents comparable descriptive statistics for the two California county-level samples. The AFDC-HAP panel includes off-census years, and so we replace median MSA 
Table 2.-Mean California County Homeless Rates and Means of the Explanatory Variables for Continuum-of-Care County-Level Cross SECTION $(1996,1997)$ AND AFDC-HAP COUNTY-LeVEL PANEL (1989-1996)

\begin{tabular}{|c|c|c|c|}
\hline \multicolumn{4}{|c|}{ Panel A. Continuum of Care } \\
\hline Variable & Full Sample & $\begin{array}{c}\text { Below-Median } \\
\text { Homelessness }\end{array}$ & $\begin{array}{c}\text { Above-Median } \\
\text { Homelessness }\end{array}$ \\
\hline \multicolumn{4}{|l|}{ Homeless per 10,000} \\
\hline Total & 117.71 (12.24) & $24.63 \quad(1.94)$ & $140.86 \quad(16.40)$ \\
\hline Individuals & $73.69(8.07)$ & $12.57 \quad(1.29)$ & $88.89(10.82)$ \\
\hline Families with children & $44.02 \quad(6.20)$ & $12.06(1.14)$ & $51.97(9.19)$ \\
\hline Housing vacancy rate (percent) & $7.078(0.560)$ & $8.998(1.243)$ & $6.601(0.608)$ \\
\hline Fair market rent & $757.083(18.920)$ & $702.242(35.080)$ & $770.723(23.82)$ \\
\hline Per capita income (1000s) & $25.452(0.790)$ & $25.284(1.769)$ & $25.494(0.902)$ \\
\hline Households $<\$ 15 \mathrm{~K}$ (percent) ${ }^{\mathrm{a}}$ & $18.957(0.710)$ & $18.943(1.524)$ & $18.961(0.841)$ \\
\hline \multicolumn{4}{|l|}{ Fair market rent/per capita } \\
\hline income (percent) & $3.013(0.052)$ & $2.882(0.081)$ & $3.046(0.070)$ \\
\hline January temperature ${ }^{\mathrm{b}}$ & $54.824(0.613)$ & $51.253(0.892)$ & $55.751(0.7510)$ \\
\hline SSI recipients per 10,000 & $188.310(9.162)$ & $177.498(14.57)$ & $190.990(12.630)$ \\
\hline Unemployment rate (percent) & $7.314(0.448)$ & $7.662(1.034)$ & $7.227(0.495)$ \\
\hline \multirow[t]{2}{*}{ Number of observations } & 50 & 25 & 25 \\
\hline & \multicolumn{2}{|c|}{ Panel B. AFDC-HAP Panel } & \\
\hline Variable & Full Sample & $\begin{array}{l}\text { Below County- } \\
\text { Specific Mean }\end{array}$ & $\begin{array}{l}\text { Above County- } \\
\text { Specific Meanc }\end{array}$ \\
\hline \multicolumn{4}{|l|}{ Cases per 10,000} \\
\hline Total & $31.49(0.001)$ & $-18.95(1.123)$ & $19.69(1.284)$ \\
\hline Permanent & $13.98 \quad(0.001)$ & $-8.47(0.604)$ & $8.80 \quad(0.631)$ \\
\hline Temporary & $17.51 \quad(0.001)$ & $-10.47(0.642)$ & $10.88 \quad(0.992)$ \\
\hline Housing vacancy rate (percent) & $6.738(0.000)$ & $.152(0.067)$ & $-.158(0.070)$ \\
\hline Fair market rent & $738.942(0.008)$ & $1.431(2.572)$ & $-1.482(2.572)$ \\
\hline Per capita income (1000s) & $22.518(0.293)$ & $195.442(0.133)$ & $-161.671(82.170)$ \\
\hline \multicolumn{4}{|l|}{ Fair market rent/per capita } \\
\hline income (percent) & $3.297(0.000)$ & $-.024(0.017)$ & $.020(0.011)$ \\
\hline January temperature $\mathrm{b}^{\mathrm{b}}$ & $53.551(0.000)$ & $-.119(0.144)$ & $.122(0.145)$ \\
\hline SSI recipients per 10,000 & $180.953(0.003)$ & $2.074(3.562)$ & $-2.154(3.262)$ \\
\hline Unemployment rate (percent) & $7.531(0.000)$ & $-.108(0.097)$ & $.113(0.094)$ \\
\hline Number of observations & 522 & 266 & 266 \\
\hline
\end{tabular}

Standard errors are in parentheses.

${ }^{a}$ This variable measures the proportion of households in the county with incomes below $\$ 15,000$ for the year 1990 . All other variables used with the continuum-of-care data are for the year 1996 .

${ }^{\mathrm{b}}$ One half of the sum of the January average high temperature and the January average low temperature.

${ }^{c}$ The means in this column are average deviations from county-specific means for each variable.

rents with the HUD fair market rent for a two-bedroom apartment. In addition, we replace median household income with per capita income and rental vacancy rates with housing vacancy rates. ${ }^{24}$ For the continuum-of-care data in panel A, the lion's share of the homeless are single, unattached individuals. As before, areas with below-median homelessness have higher housing vacancy rates, lower fair market rents, and lower ratios of rents to income. Temperate climates as well as SSI recipiency rates are positively associated with homelessness.

For the AFDC-HAP data presented in panel B, the presentation differs from that used for the other three samples. The first column presents means for the entire sample, but the second and third columns present averages of each variable measured as deviations from county means. The sample is stratified by whether the countyyear is below or above the county-specific mean. ${ }^{25}$ For

\footnotetext{
${ }^{24}$ For the continuum-of-care sample, we include the proportion of county households with income below $\$ 15,000$ as measured in the 1990 census. All other variables come from various issues of the California Statistical Abstract.

${ }^{25}$ Because the AFDC-HAP data refer to family caseloads, the homelessness rate should be normalized by the count of households. However,
}

variables positively associated with within-county variation in homelessness, means should be negative in the second column and positive in the third. The reverse holds for variables negatively associated with the incidence of homelessness.

For the HAP program, mean caseloads per 10,000 residents are comparable for both permanent and temporary assistance programs ${ }^{26}$ Housing vacancy rates are negatively associated within county, with variation in the incidence of homelessness, as is the ratio of fair market rents to personal income. These descriptive statistics in panel B suggest that these patterns are important even after controlling for persistent county-wide determinants of homelessness. None of

household counts are not observed in off-Census years. Nonetheless, the correlation in 1990 between California county population and county household counts is 0.999 ; hence, normalizing by population is unlikely to affect the results presented below.

${ }^{26}$ The mean caseloads are biased downward slightly because several months of data for the years 1991 and 1992 are missing, and the annual figures are compute by summing within year. While this affects estimates of the average incidence of homelessnes s per year, this does not affect any statistical analyses reported (because data are missing for all counties, and we include year-fixed effects in all statistical models). 
Table 3.-Logarithmic Regressions of Homelessness Rates on Measures of Housing Costs and Availability, Household Income, and labor Market Conditions Using the S-Night Homeless Counts and Burt Shelter Counts for National Samples of MSAs and Cities, 1989-1990

\begin{tabular}{|c|c|c|c|c|c|c|c|c|}
\hline & \multicolumn{4}{|c|}{ S-Night Data } & \multicolumn{4}{|c|}{ Burt Data } \\
\hline & (1) & (2) & (3) & (4) & (5) & (6) & (7) & (8) \\
\hline $\begin{array}{l}\text { Rental vacancy rate } \\
\text { (percent) }\end{array}$ & $\begin{array}{r}-0.326 \\
(0.127)\end{array}$ & - & $\begin{array}{r}-0.134 \\
(0.136)\end{array}$ & $\begin{array}{c}-0.661 \\
(0.124)\end{array}$ & $\begin{array}{c}-0.301 \\
(0.228)\end{array}$ & - & $\begin{array}{r}-0.036 \\
(0.260)\end{array}$ & $\begin{array}{r}-0.376 \\
(0.206)\end{array}$ \\
\hline $\begin{array}{l}\text { Median gross rent } \\
\text { (dollars) }\end{array}$ & $\begin{array}{c}1.503 \\
(0.251)\end{array}$ & - & $\begin{array}{c}0.397 \\
(0.489)\end{array}$ & - & $\begin{array}{c}0.724 \\
(0.437)\end{array}$ & - & $\begin{array}{c}-0.649 \\
(0.958)\end{array}$ & - \\
\hline $\begin{array}{l}\text { Households }<\$ 15 \mathrm{k} \\
\text { (percent) }\end{array}$ & - & $\begin{array}{l}1.308 \\
(0.605)\end{array}$ & $\begin{array}{c}1.392 \\
(0.626)\end{array}$ & - & - & $\begin{array}{c}0.861 \\
(1.123)\end{array}$ & $\begin{array}{c}0.620 \\
(1.180)\end{array}$ & - \\
\hline $\begin{array}{l}\text { Median HH income } \\
\text { (dollars) }\end{array}$ & - & $\begin{array}{c}3.928 \\
(0.716)\end{array}$ & $\begin{array}{c}3.404 \\
(0.849)\end{array}$ & - & - & $\begin{array}{c}2.212 \\
(1.300)\end{array}$ & $\begin{array}{c}2.622 \\
(1.642)\end{array}$ & - \\
\hline $\begin{array}{l}\text { Median gross rent/ } \\
\text { median } \mathrm{HH} \text { income }\end{array}$ & - & - & - & $\begin{array}{c}0.806 \\
(0.510)\end{array}$ & - & - & - & $\begin{array}{r}-0.219 \\
(0.901)\end{array}$ \\
\hline $\begin{array}{l}\text { Unemployment rate } \\
\text { (percent) }\end{array}$ & - & $\begin{array}{c}-0.183 \\
(0.233)\end{array}$ & $\begin{array}{c}-0.185 \\
(0.239)\end{array}$ & $\begin{array}{c}-0.118 \\
(0.217)\end{array}$ & - & $\begin{array}{r}-0.680 \\
(0.454)\end{array}$ & $\begin{array}{r}-0.614 \\
(0.468)\end{array}$ & $\begin{array}{c}-0.638 \\
(0.346)\end{array}$ \\
\hline $\begin{array}{l}\text { Change in state mental } \\
\text { patients (per 100,000) }\end{array}$ & $\begin{array}{c}0.0014 \\
(0.0021)\end{array}$ & $\begin{array}{c}0.0026 \\
(0.0022)\end{array}$ & $\begin{array}{c}0.0026 \\
(0.0022)\end{array}$ & $\begin{array}{c}0.0012 \\
(0.0023)\end{array}$ & $\begin{array}{c}-0.011 \\
(0.004)\end{array}$ & $\begin{array}{c}-0.009 \\
(0.003)\end{array}$ & $\begin{array}{c}-0.009 \\
(0.004)\end{array}$ & $\begin{array}{c}-0.011 \\
(0.004)\end{array}$ \\
\hline $\begin{array}{l}\text { Change in state prisoners } \\
\text { (per 100,000) }\end{array}$ & $\begin{array}{c}0.0004 \\
(0.0004)\end{array}$ & $\begin{array}{c}0.0005 \\
(0.0004)\end{array}$ & $\begin{array}{c}0.0006 \\
(0.0004)\end{array}$ & $\begin{array}{c}0.0011 \\
(0.0004)\end{array}$ & $\begin{array}{r}-0.0006 \\
(0.0006)\end{array}$ & $\begin{array}{c}-0.0005 \\
(0.0007)\end{array}$ & $\begin{array}{l}-0.0005 \\
(0.0007)\end{array}$ & $\begin{array}{r}-0.0004 \\
(0.0006)\end{array}$ \\
\hline $\begin{array}{l}\text { January temperature } \\
\text { (degrees Fahrenheit) }\end{array}$ & $\begin{array}{c}0.059 \\
(0.122)\end{array}$ & $\begin{array}{c}0.370 \\
(0.109)\end{array}$ & $\begin{array}{c}0.324 \\
(0.140)\end{array}$ & $\begin{array}{c}0.234 \\
(0.154)\end{array}$ & $\begin{array}{c}0.011 \\
(0.188)\end{array}$ & $\begin{array}{c}0.069 \\
(0.179)\end{array}$ & $\begin{array}{c}0.180 \\
(0.236)\end{array}$ & $\begin{array}{c}0.074 \\
(0.234)\end{array}$ \\
\hline $\begin{array}{l}\text { SSI recipients } \\
\quad(\text { per } 100,000)\end{array}$ & $\begin{array}{c}0.014 \\
(0.107)\end{array}$ & $\begin{array}{c}0.085 \\
(0.131)\end{array}$ & $\begin{array}{c}0.001 \\
(0.148)\end{array}$ & $\begin{array}{r}-0.057 \\
(0.147)\end{array}$ & $\begin{array}{r}-0.398 \\
(0.188)\end{array}$ & $\begin{array}{l}-0.108 \\
(0.226)\end{array}$ & $\begin{array}{r}-0.049 \\
(0.282)\end{array}$ & $\begin{array}{r}-0.114 \\
(0.260)\end{array}$ \\
\hline$R^{2}$ & 0.427 & 0.462 & 0.465 & 0.347 & 0.285 & 0.320 & 0.324 & 0.290 \\
\hline $\boldsymbol{F}$-stat* & 35.729 & - & 0.730 & 89.175 & 4.535 & - & 0.269 & 1.722 \\
\hline$(\boldsymbol{p}$-value $)$ & $(0.0001)$ & & $(0.482)$ & $(0.0001)$ & $(0.133)$ & & $(0.765)$ & $(0.184)$ \\
\hline Sample size & 246 & 246 & 246 & 246 & 102 & 102 & 102 & 102 \\
\hline
\end{tabular}

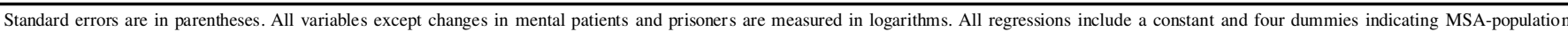
quartiles.

$* \boldsymbol{F}$-statistic from a test of the joint significance of the two housing variables.

the other differences across subsamples in the explanatory variables are significant in the unadjusted data.

\section{Results}

In this section, we present regression results from models using the four measures of homelessness as dependent variables. Table 3 presents results for the two national data sets. All variables with the exception of the inpatient and prison populations are measured in logarithms, and the coefficient estimates are elasticities. For each data set, we estimate four specifications: the first controls for rental vacancy rates and median rents; the second specification incorporates household income and labor market conditions; the third adds the housing market, income, and labor market variables simultaneously; and the fourth specification introduces the ratio of median rents to household incomes. All models include controls for 1980 to 1990 changes in state mental hospital populations, changes in state prison populations, the logarithm of January temperature (the average of the January daily high and low in 1990), and the logarithm of SSI recipients per 100,000 state residents. For all models including housing costs measures, we conduct $\boldsymbol{F}$-tests of the joint significance of the housing variables.

Regression (1), based upon the S-night data, reports a significant negative effect of rental vacancy rates and a positive effect of median rents on homelessness. The two housing market variables are both jointly and independently significant at the $1 \%$ level. Specification (2) indicates that increased poverty and dispersion in the income distribution is associated with higher levels of homelessness. Recall that higher median rents, holding the proportion of household in the lower tail of the income distribution constant, indicate greater income inequality. These income patterns are also evident in specification (3), which adds the housing market variables. Controlling for income and the percentage poor, however, reduces the magnitude and significance of the point estimates for the coefficients of the housing variables. In the final S-night regression, rental vacancy rates have a significant negative effect on homelessness, although the rents-to-income ratio has a positive effect (significant at $10 \%$ ) on homelessness. Again, both housing market variables are jointly significant at the $1 \%$ level. Hence, with the exception of specification (3), housing market variables have the predicted effects on the S-night homelessness measure. Moreover, the results consistently indicate that greater income inequality is associated with higher levels of homelessness.

Now consider the other variables listed in the table. All of the point estimates for the unemployment rate coefficients are negative and insignificant, as are those for the SSI population. In addition, there are no discernable effects of deinstitutionalization, as measured by the changes in the inpatient population of mental hospitals. Nor are there measurable effects of changes in the prison population on the incidence of homelessness (except in the final specification in which there is a positive significant effect of 
Table 4.-Logarithmic Regressions of Homeless Rates on Measures of Housing Availability and Labor Market Conditions using ContinuUM-OF-CARE Counts FOR CALIFORnia Counties, 1996-1997

\begin{tabular}{|c|c|c|c|c|c|c|c|c|}
\hline & \multicolumn{4}{|c|}{ Homeless Individuals } & \multicolumn{4}{|c|}{ Homeless Members of Families with Children } \\
\hline & (1) & $(2)$ & (3) & (4) & $(5)$ & (6) & (7) & (8) \\
\hline $\begin{array}{l}\text { Housing vacancy rate } \\
\quad \text { (percent) }\end{array}$ & $\begin{array}{r}-0.847 \\
(0.375)\end{array}$ & - & $\begin{array}{r}-0.500 \\
(0.416)\end{array}$ & $\begin{array}{r}-0.896 \\
(0.319)\end{array}$ & $\begin{array}{c}0.319 \\
(0.465)\end{array}$ & - & $\begin{array}{c}0.999 \\
(0.491)\end{array}$ & $\begin{array}{c}0.408 \\
(0.391)\end{array}$ \\
\hline $\begin{array}{l}\text { Fair market rent } \\
\text { (dollars) }\end{array}$ & $\begin{array}{c}1.053 \\
(1.031)\end{array}$ & - & $\begin{array}{r}-1.645 \\
(1.768)\end{array}$ & - & $\begin{array}{c}0.492 \\
(1.276)\end{array}$ & - & $\begin{array}{r}-2.507 \\
(2.079)\end{array}$ & - \\
\hline $\begin{array}{l}\text { Households with } \\
\text { income }<\$ 15,000 \\
\text { (percent) }\end{array}$ & - & $\begin{array}{r}-2.381 \\
(1.343)\end{array}$ & $\begin{array}{r}-1.567 \\
(1.493)\end{array}$ & - & - & $\begin{array}{r}-2.600 \\
(1.660)\end{array}$ & $\begin{array}{r}-4.085 \\
(1.755)\end{array}$ & - \\
\hline $\begin{array}{l}\text { Per capita income } \\
\quad \text { (dollars) }\end{array}$ & - & $\begin{array}{c}1.696 \\
(1.070)\end{array}$ & $\begin{array}{c}2.603 \\
(1.846)\end{array}$ & - & - & $\begin{array}{c}-0.721 \\
(1.321)\end{array}$ & $\begin{array}{c}2.397 \\
(2.170)\end{array}$ & - \\
\hline $\begin{array}{l}\text { Fair market rent/per } \\
\text { capita income }\end{array}$ & - & - & - & $\begin{array}{r}-2.341 \\
(1.688)\end{array}$ & - & - & - & $\begin{array}{r}-3.164 \\
(2.062)\end{array}$ \\
\hline $\begin{array}{l}\text { Unemployment rate } \\
\text { (percent) }\end{array}$ & - & $\begin{array}{c}0.465 \\
(0.638)\end{array}$ & $\begin{array}{c}0.436 \\
(0.720)\end{array}$ & $\begin{array}{r}-0.180 \\
(0.583)\end{array}$ & - & $\begin{array}{r}-0.210 \\
(0.788)\end{array}$ & $\begin{array}{c}0.734 \\
(0.846)\end{array}$ & $\begin{array}{r}-0.101 \\
(0.713)\end{array}$ \\
\hline $\begin{array}{l}\text { January temperature } \\
\quad \text { (degrees Fahrenheit) }\end{array}$ & $\begin{array}{c}5.748 \\
(1.961)\end{array}$ & $\begin{array}{c}7.688 \\
(1.669)\end{array}$ & $\begin{array}{c}9.006 \\
(2.403)\end{array}$ & $\begin{array}{c}9.348 \\
(2.307)\end{array}$ & $\begin{array}{c}1.944 \\
(2.431)\end{array}$ & $\begin{array}{c}3.255 \\
(2.065)\end{array}$ & $\begin{array}{c}6.326 \\
(2.828)\end{array}$ & $\begin{array}{c}5.818 \\
(2.822)\end{array}$ \\
\hline SSI recipients & 1.230 & 2.885 & 2.341 & 1.490 & 0.132 & 1.991 & 2.740 & 0.526 \\
\hline$($ per 10,000$)$ & $(0.431)$ & $(0.878)$ & $(0.965)$ & $(0.527)$ & $(0.533)$ & $(1.085)$ & $(1.134)$ & $(0.644)$ \\
\hline $\boldsymbol{R}^{2}$ & 0.418 & 0.462 & 0.487 & 0.397 & 0.042 & 0.118 & 0.239 & 0.133 \\
\hline $\boldsymbol{F}$-Stat* & 6.082 & - & 1.019 & 5.119 & 0.236 & - & 3.192 & 1.640 \\
\hline$(p$-value $)$ & $(0.004)$ & & $(0.369)$ & $(0.010)$ & $(0.797)$ & & $(0.052)$ & $(0.206)$ \\
\hline Sample size & 49 & 49 & 49 & 49 & 48 & 48 & 48 & 48 \\
\hline
\end{tabular}

All regressions include a constant. Standard errors are in parentheses. All variables are measured in logarithms. All regression are weighted by county population.

${ }^{a}$ Measured in January 1996 using the method reported in table 1 and 2

* $\boldsymbol{F}$-statistic from a test of the joint significance of the two housing variables.

incarceration rates on homelessness). Again, these results for changes in institutionalized populations suggest that these factors deserve less of the "blame" for increased homelessness than is commonly attributed to them. A priori, one would predict negative effects of changes in mental hospital populations as well as prison populations on homelessness, which are patterns that our regression results do not support. Finally, in three of the four specifications, milder winter weather is associated with a significantly higher incidence of homelessness.

For the Burt shelter counts, vacancy rates have insignificant effects in the first and third specification, and a weakly significant negative effect in the final specification. Median rents have the expected positive and significant effect in the first specification only. There is no effect of the proportion of low-income households upon homelessness in any of the specifications, and median household incomes are positively associated with the incidence of homelessness. Finally, the ratio of rents to household income is insignificant in the final specification. The housing variables are jointly significant in the first specification only. Moreover, the unemployment rate, January temperatures, and the SSI recipient populations are, for the most part, insignificant.

One variable that is consistently significant is the change in the state inpatient population. Unlike as in the results for the S-night sample, decreases in the state mental hospital population cause increases in shelter capacity. In addition, the point estimates on the prison populations are negative, although insignificant. These patterns are consistent with an effect of changes in institutional populations on homelessness, but they are also consistent with the view that shelter capacity reflects variation in policy responses rather than changes in latent homelessness.

A further departure from the S-night results that may speak to this issue concerns the findings for January temperature. For the Burt models, January temperature exerts small and insignificant effects, although, for the S-Night data, this variable is generally positive and significant. This difference may reflect the policy decisions of local providers to expand capacity during cold times. This interpretation casts some doubt on the shelter deinstitutionalization results in particular, and the use of shelter beds as a dependent variable more generally. Alternatively, one might interpret these results as reflecting the poor quality of the S-night enumeration. Although we cannot claim to reconcile these differences in findings, the performance of the housing variables and temperature for the two California data sets (especially the panel data set) may indicate which set of national results is the exception and which the rule.

Table 4 presents regression results using two measures of homelessness from the continuum-of-care cross sections for California. For the first four regressions, the dependent variable is homeless individuals per 10,000 county residents, whereas the next four regressions present separate results for homeless members of families with children per 10,000 residents. Again, all variables are measured in logarithms.

The results for homeless individuals parallel the patterns observed in the S-night models. Housing-vacancy rates have the expected negative effect in all specifications and are significant in two of the three (specifications (1) and (4)). Fair market rents are insignificant in all regressions, 
Table 5.-Logarithmic Regressions of Homeless Rates on Measures of Housing Costs and Availability, Per Capita Incomes, and Labor Market Conditions using AFDC-HAP Counts for California Counties, 1989-1997

\begin{tabular}{|c|c|c|c|c|c|c|c|c|}
\hline & \multicolumn{4}{|c|}{ Permanent Caseload } & \multicolumn{4}{|c|}{ Temporary Caseload } \\
\hline & (1) & (2) & (3) & (4) & (5) & (6) & (7) & (8) \\
\hline $\begin{array}{l}\text { Vacancy rate } \\
\text { (percent) }\end{array}$ & $\begin{array}{r}-0.834 \\
(0.109)\end{array}$ & - & $\begin{array}{r}-0.763 \\
(0.113)\end{array}$ & $\begin{array}{r}-0.769 \\
(0.109)\end{array}$ & $\begin{array}{r}-0.431 \\
(0.103)\end{array}$ & - & $\begin{array}{r}-0.494 \\
(0.100)\end{array}$ & $\begin{array}{r}-0.448 \\
(0.097)\end{array}$ \\
\hline $\begin{array}{l}\text { Fair market rent } \\
\quad \text { (dollar) }\end{array}$ & $\begin{array}{c}1.884 \\
(0.316)\end{array}$ & - & $\begin{array}{c}1.286 \\
(0.322)\end{array}$ & - & $\begin{array}{c}0.045 \\
(0.299)\end{array}$ & - & $\begin{array}{c}0.916 \\
(0.287)\end{array}$ & - \\
\hline $\begin{array}{l}\text { Per capita income } \\
\quad \text { (dollar) }\end{array}$ & - & $\begin{array}{r}-1.995 \\
\quad(.529)\end{array}$ & $\begin{array}{c}-1.407 \\
(0.508)\end{array}$ & - & - & $\begin{array}{c}-0.361 \\
(0.459)\end{array}$ & $\begin{array}{l}0.008 \\
(0.454)\end{array}$ & - \\
\hline $\begin{array}{l}\text { Fair market rent/ } \\
\text { per capita income }\end{array}$ & - & - & - & $\begin{array}{c}1.320 \\
(0.277)\end{array}$ & - & - & - & $\begin{array}{c}0.658 \\
(0.248)\end{array}$ \\
\hline $\begin{array}{l}\text { Unemployment rate } \\
\text { (percent) }\end{array}$ & - & $\begin{array}{l}-0.272 \\
(0.175)\end{array}$ & $\begin{array}{c}0.115 \\
(0.183)\end{array}$ & $\begin{array}{c}0.124 \\
(0.177)\end{array}$ & - & $\begin{array}{l}-0.526 \\
(0.150)\end{array}$ & $\begin{array}{r}-0.286 \\
(0.164)\end{array}$ & $\begin{array}{c}-0.356 \\
(0.159)\end{array}$ \\
\hline $\begin{array}{l}\text { January temperature } \\
\text { (degrees Fahrenheit) }\end{array}$ & $\begin{array}{c}1.074 \\
(0.454)\end{array}$ & $\begin{array}{l}1.718 \\
(0.446)\end{array}$ & $\begin{array}{c}1.299 \\
(0.429)\end{array}$ & $\begin{array}{l}1.290 \\
(0.426)\end{array}$ & $\begin{array}{c}2.506 \\
(0.429)\end{array}$ & $\begin{array}{l}2.283 \\
(0.387)\end{array}$ & $\begin{array}{l}2.025 \\
(0.383)\end{array}$ & $\begin{array}{c}2.098 \\
(0.382)\end{array}$ \\
\hline $\begin{array}{l}\text { SSI recipients per } \\
\quad 10,000\end{array}$ & $\begin{array}{c}1.241 \\
(0.387)\end{array}$ & $\begin{array}{c}-0.218 \\
(0.478)\end{array}$ & $\begin{array}{c}0.311 \\
(0.455)\end{array}$ & $\begin{array}{c}0.321 \\
(0.451)\end{array}$ & $\begin{array}{c}-0.068 \\
(0.367)\end{array}$ & $\begin{array}{c}0.084 \\
(0.417)\end{array}$ & $\begin{array}{c}0.446 \\
(0.408)\end{array}$ & $\begin{array}{c}0.364 \\
(0.407)\end{array}$ \\
\hline $\begin{array}{l}\boldsymbol{F} \text {-stat* } \\
(\boldsymbol{p} \text {-value })\end{array}$ & $\begin{array}{l}39.235 \\
(0.0001)\end{array}$ & - & $\begin{array}{l}27.467 \\
(0.0001)\end{array}$ & $\begin{array}{l}35.592 \\
(0.0001)\end{array}$ & $\begin{array}{l}8.835 \\
(0.0002)\end{array}$ & - & $\begin{array}{l}15.092 \\
(0.0001)\end{array}$ & $\begin{array}{l}13.816 \\
(0.0001)\end{array}$ \\
\hline Sample size & 511 & 458 & 458 & 458 & 509 & 456 & 456 & 456 \\
\hline
\end{tabular}

All regressions include a complete set of 58 county-fixed effects and nine year-fixed effects. The dependent variable is the log of the respective caseload per 10,000 county residents. All variables are measured in logs. All regressions are weighted by county population.

$* \boldsymbol{F}$-statistic from a test of the joint significance of the two housing variables.

and the ratio of rents to income is also insignificant. The effects of the proportion poor and per capita income are insignificant in all specifications. In addition, the unemployment rate has no discernable effect. The variables that have consistently significant effects are the January temperature and the SSI recipient population. The effects of both variables are positive.

For the models using homelessness in families with children, the housing market variables perform poorly (and are insignificant in most specifications) as does personal income, the proportion of low-income households, and the unemployment rate. The only variable that exerts a significant effect in more than one specification with the theoretically predicted sign is the January temperature. Hence, the results from the continuum-of-care regressions yield only weak evidence on the importance of housing and income variables on the incidence of homelessness. The evidence is based on only fifty observations, however, and as noted above the dependent variable is often measured in quite different ways.

Our final set of results using the AFDC-HAP panel is presented in table 5 . The table presents separate results for homeless households receiving permanent assistance and homeless households receiving temporary assistance. Again, these variables are expressed per 10,000 county residents, and all are measured in logarithms. The model specifications are similar to those of the other three measures of homelessness, with a few differences. First, all models include a full set of county and year fixed effects, capturing unobserved time-invariant heterogeneity across counties and common year-to-year caseload shifts. Second, because eight of the nine years of the panel are not census years, we are unable to control for intracounty variation over time in the proportion of households with low incomes. Finally, estimates of per capita income for 1997 are not yet available, so the sample size for regressions that omit this variable is slightly larger than for regressions when per capita income is included in the specification.

The results in table 5 provide the strongest evidence that housing market tightness is an important determinant of homeless. For permanent caseloads, vacancy rates have a strong negative and statistically significant effect (at the 1\% level) on the incidence of homelessness. Moreover, these elasticity estimates are quite similar across specifications. In the two specifications including fair market rents (specifications (1) and (3)), rents exhibit a significant positive effect on the incidence of homelessness as predicted by theory. In addition, the specification including the ratio of rents to income indicates a strong positive effect. Hence, for homelessness, as measured by the incidence of homeless households seeking permanent assistance, measures of housing market tightness consistently exhibit strong and statistically significant effects, which is consistent with the predictions of theory. We also find a negative and significant effect of per capita income. There are no important effects of county unemployment rates and no consistent and significant effects of the SSI populations across specifications. Similar to the results from the S-night and continuum-of-care data sets, the results in table 5 also indicate that warmer weather is positively associated with homelessness.

The patterns for families seeking temporary assistance are similar to those for the permanent caseloads. Vacancy rates are consistently negative and significant, and fair market rents have an insignificant effect in the first specification and a highly significant and positive effect in the third specification. The ratio of rents to income has a positive significant effect on the incidence of homelessness, and per capita income is insignificant in all regressions. Again, we find significant positive effects of temperature. 
The ability to control for unobserved intercounty heterogeneity within a single state leads us to believe that the AFDC-HAP results are the most reliable. Hence, one might judge the results from the previous data sets against the findings from AFDC-HAP. The findings for S-night are considerably closer to the AFDC-HAP results than are the findings using shelter bed counts. In particular, housing costs matter, and there is a consistent behavioral response among the poor and potentially homeless to the weather. The fact that we do not observe these weather effects in the shelter-count models (a result consistently present for the other three data sets) casts doubt on the remainder of the findings from these regressions. Concerning the continuumof-care data set, although we do observe positive temperature effects, the results for the housing variables are mixed at best. Again, this may be due in part to the extremely small sample size as well as to the heterogeneity in methods used to estimate the homeless population across counties.

As a summary of the statistical analysis, we combined the four data sets and estimated a model specification comparable to the final specification for each outcome presented in tables 3 through 5 (including separate observations for alternative subgroups within samples). The results from this summary regression yield elasticity estimates of -0.66 for the vacancy rate, 0.35 for the ratio of rents to incomes, -0.30 for the unemployment rates, 0.40 for January temperature, and -0.20 for the SSI population.

These estimates are significant at the $1 \%$ level with the exception of the rents-to-income ratio elasticity, which is significant at the $10 \%$ level. $^{27}$

\section{Interpretation and Conclusion}

The results presented in tables 3 through 5 exhibit several consistent patterns. Tighter housing markets are positively associated with higher levels of homelessness. In most of the models estimated, the housing or rental vacancy rate exerts a negative and statistically significant effect on homelessness, and measures of housing costs such as median rents and rent-to-income ratios exert positive and significant effects. We find a consistent negative effect of weather conditions on the incidence of homelessness: colder weather is clearly associated with lower rates. These findings support models of homelessness that emphasize rational choice among the extremely poor. The evidence regarding the effect of deinstitutionalization is mixed, with no discernable effect on homelessness as measured by the S-night counts and a statistically significant effect on the Burt counts of shelter beds.

The quantitative analysis suggests that relatively small changes in housing market conditions can have substantial

\footnotetext{
${ }^{27}$ This model includes separate intercepts for the various subgroups and, for the AFDC-HAP outcomes, indicators for county and year. Hence, the regression provides estimates of the effects of vacancy rates and the ratios of rents to incomes that are essentially a weighted average of the estimates from the various samples.
}

effects upon rates of homelessness. Consider, for example, a reduction in the rate of homelessness by one-fourth. The quantitative results suggest that this could be achieved in the national sample of housing markets by a one percentage point increase in the vacancy rate (from an average of $8.4 \%$ ) combined with a decrease in average monthly rent-toincome ratios from $17.5 \%$ to $16.8 \%$ (median rent to median household income). For the sample of California counties, a $25 \%$ reduction in the incidence of homelessness could be achieved by a one-point increase in the vacancy rate (from an average of $6.7 \%$ ) combined with a decrease in average monthly rent-to-income ratios from $39.6 \%$ to $39.4 \%$ (median fair market rent to average per capita income). Given the nature of the underlying data, the accuracy of these precise estimates is open to question. Nevertheless, the calculations suggest that modest changes in housing market conditions can have substantial effects upon the incidence of homelessness.

These consistent statistical results and simulations contrast with the conventional wisdom regarding the causes of homelessness. In particular, the results suggest that a simple economic model of the tough choices faced by households and individuals in the extreme lower tail of the income distribution goes a long way towards explaining the problem. Most importantly, our findings suggest that homelessness may be combated by modest supply policies combined with housing assistance directed to those for whom housing costs consume a large share of their low incomes.

\section{REFERENCES}

Bonnewit, Natalie, "Estimating California's Homeless Population," unpublished master's thesis, Department of City and Regional Planning, University of California, Berkeley (1998).

Burt, Martha, Over the Edge: The Growth of Homelessness During the 1980s (New York: Russell Sage Foundation, 1992).

Burt, Martha, and Barbara S. Cohen, America's Homeless: Numbers, Characteristics and Programs That Serve Them (Washingto n D.C.: The Urban Institute, 1989).

Cordray, David S., and Georgine M. Pion, "What's behind the Numbers? Definitional Issues in Counting the Homeless," in Dennis P. Culhane and Steven P. Hornburg (Eds.), Understanding Homelessness: New Policy and Research Initiatives (Washington D.C.: Fannie Mae Foundation, 1997).

Cragg, Michael, and Brendan O'Flaherty, "Do Homeless Shelter Conditions Determine Shelter Population? The Case of the Dinkins Deluge," Journal of Urban Economics 46(3) (1999) 377-415.

Culhane, Dennis P., Edmund F. Dejowski, Julie Ibanez, Elizabeth Needham, and Irene Macchia, "Public Shelter Admission Rates in Philadelphia and New York: The Implications of Turnover for Sheltered Population Counts," Housing Policy Debate 5(2) (1999), 107-139.

Ditton, Paula M., "Mental Health and Treatment of Inmates and Probationers," Bureau of Justice Statistics Special Report, NCJ 174463, U.S. Department of Justice (1999).

Early, Dirk W., and Edgar O. Olsen, "Rent Control and Homelessness," Regional Science and Urban Economics 28(6) (1998), 797-816.

Edin, Katheryn, "Counting Chicago's Homeless: An Assessment of the Census Bureau's 'Street and Shelter Night,'" Evaluation Review 16(4) (1992), 365-375.

Fitzpatrick, Suzanne, "Homelessness in the European Union" (pp. 197219), in Mark Kleinman, Walter Matznetter, and Mark Stephen s (Eds.), European Integration and Housing Prices (London: Routledge, 1998). 
Gabriel, Stuart A., Joe P. Mattey, and William L. Wascher, "House Price Differential and Dynamics: Evidence from the Los Angeles and San Francisco Metropolitan Areas," Federal Reserve Board of San Francisco Economic Review (1) (1999), 3-21.

Honig, Margorie, and Randall K. Filer, "Causes of Inter-city Variation in Homelessness," American Economic Review 83(1) (1993), 248255.

Hombs, Mary Ellen, and Mitch Snyder, Homelessness in America: A Forced March to Nowhere (Washington D.C.: Community on Creative Non-Violence, 1982).

Hopper, Kim, "Counting the Homeless: S-Night in New York," Evaluation Review, 16(4) (1992), 376-388.

Hudson, Christopher G., "The Homeless of Massachusetts : An Analysis of the 1990 U.S. Census S-Night Data," New England Journal of Public Policy 9(1) (1993) 79-100.

Jencks, Christopher, The Homeless (Cambridge: Harvard University Press, 1994).

Liska, Allen E., Fred E. Markowitz, Rachel B. Whalet, and Paul Bellair, "Modelling the Relationship Between Criminal Justice and Mental Health Systems," American Journal of Sociology 104(6) (1999), 1744-1775.

Levitt, Steven D. "The Effect of Prison Population Size on Crime Rates: Evidence from Prison Overcrowding Legislation," Quarterly Journal of Economics 111(2) (1996) 319-352.

Malpezzi, Stephen, Gregory H. Chun, and Richard K. Green, "New Place-to-Place Housing Price Indexes for U.S. Metropolitan Areas, and Their Determinants," Real Estate Economics 26(2) (1996), 235-274

Martin, Elizabeth, "Assessment of S-Night Street Enumeration in the 1990 Census," Evaluation Review 16(4) (1992), 418-438.

Mansur, Erin, John M. Quigley, Steven Raphael, and Eugene Smolensky, "Examining Policies to Reduce Homelessness in California Using a General Equilibriu m Model of the Housing Market," U.C. Berkeley Program on Housing and Urban Policy working paper series W00-006 (2000)

O'Flaherty, Brendan, "An Economic Theory of Homelessness and Housing," Journal of Housing Economics 4(1) (1995), 13-49.

, Making Room: The Economics of Homelessness (Cambridge: Harvard University Press, 1996).
Phelan, Jo C., and Bruce G. Link, "Who Are the Homeless? Reconsidering the Stability and Composition of the Homeless Population," American Journal of Public Health 89(9) (1999), 1334-1338.

Raphael, Steven, "The Deinstitutionalization of the Mentally Ill and Growth in the U.S. Prison Population: 1971 to 1993," unpublished manuscript (2000).

Reed, Deborah, Melissa Glenn-Haber, and Laura Mameesh, The Distribution of Income In California (San Francisco: Public Policy Institute of California, 1996).

Reuter, Peter, Robert MacCoun, and Patrick Murphy, Money From Crime: A Study of the Economics of Drug Dealing in Washington, D.C. (Santa Monica: Rand Corporation, 1990).

Rosenthal, Larry A., "Counting the Uncountable: A Survey of Data Sources on the Size of the Homeless Population," unpublished manuscript (2000).

Rossi, Peter H., Down and Out in America: The Origins of Homelessness (Chicago: University of Chicago Press, 1989).

Shlay, Anne, and Peter Rossi, "Social Science Research and Contemporary Studies of Homelessness," Annual Review of Sociology 18 (1992) 129-160.

Taeuber, Cynthia S., (Ed.), Conference Proceedings for Enumerating Homeless Persons: Methods and Data Needs (Washington D.C.: U.S. Bureau of the Census, 1991).

Torrey, E. Fuller, Out of the Shadows: Confronting America's Mental Illness Crisis (New York: John Wiley and Sons, 1997).

Tucker, William, "Where Do the Homeless Come From?" National Review 39 (September 25, 1987), 32-43.

U.S. Department of Housing and Urban Development, A Report to the Secretary on the Homeless and Emergency Shelters (Washington, D.C.: Department of Housing and Urban Development, Office of Policy Development and Research, 1984).

, Continuum-of-Care and HOPWA Applications (Washington, D.C.: Department of Housing and Urban Development, 1994).

U.S. House of Representatives, Committee on Ways and Means, 1991 Green Book (Washington D.C.: Government Printing Office, 1991).

Write, James D., and Joel A. Devine, "Counting the Homeless: The Census Bureau's 'S-Night' in Five U.S. Cities," Evaluation Review 16(4) (1992) 355-364. 